\title{
THE PORTRAIT OF AUTHENTIC MATERIAL IN TEACHING ENGLISH FOR SPECIFIC PURPOSES (ESP)
}

\author{
Vianty Wulandari \\ University of Al Azhar Indonesia \\ wulandarivianty@uai.ac.id \\ Edy Waloyo \\ Syekh Nurjati State Islamic Institute Cirebon \\ edywaloyo@syekhnurjati.ac.id
}

\begin{abstract}
The aim of this research is to investigate teaching and learning English for Specific Purposes (ESP) at SMK Negeri 2 Cirebon using the authentic materials. The method which used in this research is descriptive qualitative research. The techniques of collecting data are observation, interview and document study to know the process of teaching and learning ESP using authentic materials. The population in this research is students of hotel accommodation program. The sample of this research was a hotel accommodation class and an English teacher. The validity data in this research are credibility, dependability, transferability and conformability. Credibility refers to triangulation data of the observation, interview transcriptions and documents. Dependability refers to parallels prove, transferability refers to study previous document and conformability refers to the research objectivity. The result of this research shows that the process using authentic materials in teaching ESP works good, because the teacher selected the authentic learning materials appropriately relevance with students' needs and interests. Therefore, the teacher has positive response and the students also have the positive responses to the teaching and learning ESP using authentic materials. In this research, the researcher found good portrait of authentic materials toward teaching and learning ESP at hotel accommodation program and the positive response between teacher and students about teaching and learning ESP using the authentic material.
\end{abstract}

Keywords: ESP, Authentic Materials, Teaching Speaking

\section{BACKGROUND}

English as an international language was already language used widely for communication and it takes place to deal with academic discourse around the world. The Indonesian government has realized the importance of English and has decided that English as a compulsory subject at the secondary school and senior high school (Fachrurrazy: 2014). It is evidence that English has big role in Indonesia education world. These issues deal with how English is being taught and what type of English materials is being taught. Long (2007: 121) remarks that, teaching English should be focus on target discourse, it should restricted as the language skills to be learned. It can be stated that English need to be specify to the target of communication. These statements in line with the teaching and learning process in Vocational High School, the curriculum was designed English as the specific purposes (ESP) as the preparation of students overcoming the professional workplace. As is noted by Palmero (2003) ESP is fundamentally based on two 
teaching paradigms, namely pragmatic and cognitive. Under pragmatic paradigm the focus is on language in use, and emphasis is put on contextualized teaching, using authentic materials, and attention to sociolinguistic aspects of interaction. Furthermore, cognitive teaching paradigm puts emphasis on students' responsibility on their own progress and the insertion of creative tasks.

Concerning to the teaching of English for Specific Purposes (ESP), Basturkmen (2006:133) states the existence of five board objectives on which specific teaching process are should have to reveal subject-specific language use; it is to demonstrate how the language is used in the target setting, to develop target performance competencies; it is concerned with language and needed skills to be competent, to teach underlying knowledge, it is to focus on developing students' knowledge of field of the study or work in addition to their language skill, to develop strategic competence that linked between context of situation and language knowledge and enables successful and efficient communication and to foster critical awareness.

English for Specific Purposes (ESP) teaching and learning process necessarily go through different stages. Dudley-Evans and Johns in Eddine(2016) maintain that the key stages in ESP are needs identification and analysis, course and syllabus design, material selection and production, teaching and learning, and evaluation. Designing an effective ESP course is governed by essential parameters above that have to be studied and analyzed as a pre-design process, a detailed description of each steps as follow: (1) Need identification and analysis: it envelop the general requirements of both learners and institutions, their profiles and attitudes, also the existing materials. (2) Course and syllabus design: the results of learners needs identification and analysis (NIA) lead to setting up general statements and what would be achieved at the end of the courses. (3)Teaching and learning: organizing the syllabus content "through the sequencing of materials whose layout and presentation should form a continuum". (4) Assessment: gathering data regarding syllabus before or during the course implementation let to readjust the content of the syllabus. (5) Evaluation: ESP course itself needs to be evaluated, whether the sets of objectives designed were achieved or not, to reach the course aims.

English for Specific Purposes (ESP) is a subset of English as a second or foreign language. Its course design is the product of a dynamic interaction between these elements which are not separated, linearly-related activities, rather, they represent phases which overlap and are interdependent. Therefore, the achievement of ESP courses are: those where the syllabus and the material are determined by the prior analysis of the communication needs of the learner (Mumby in Eddine, 2016). It is not principally determined by criteria of general education but by functional and practical English language requirements of the learner, or it adapted from the learner needs and interest.

Teaching materials are the main components in most language teaching such English for Specific Purposes (ESP). Based on Richards (2001: 251) which summarizes the roles of instructional materials in the language teaching are resource for presentation materials (spoken and written), source of activities for learners practice and make communicative interaction, source reference of stimulation and ideas for classroom activities, syllabus (where teaching materials reflect learning objectives that have already been determined), additional source to support teachers' who have less experiences and have not gain the confidence. Instructional materials generally served as the basis for many languages practice that applies in the classroom activities.

English for Specific Purposes (ESP) teaching process considered alternatives to use authentic material as the teaching materials. Because the authentic material provides the 
real-life communication and it is language where no concessions are made to foreign speakers. It is natural language used by native or competent speaker of language. This is such illustrations of what students will encounter in real life if they come into contact with target language speaker. For example, authentic material which has been carelessly chosen can be extremely demotivating for students since they will not understand it. Instead of encouraging failure, teachers should let students read and listen to things students can understand. Authentic materials can be used by students at fairly low levels, however, if the tasks that go with it are well-designed and help students understand it better, rather than showing them how little they know.

The authentic material is used to identify as the contextual material or real life material. Authentic material refers to the use of texts, selected videos, photograph, and other teaching resources that were not specially prepared for pedagogical purposes in teaching. They are commonly contrasted to the created materials, the course book or textbook, and other developing instructional resources. To find out the advantages of the authentic materials, the researchers have been assessed those advantages while it occurs in the classroom, as it follows: (1) help prepare learners for the real world of communication; (2) guide learners toward the language they need for their particular contexts; and (3) motivate learners to communicate, because it helps make communication real.

Besides that, authentic materials are kinds of material which are taken from the real world situation and it is not pedagogical purposes of language teaching. Wallace (1992:145) defines the authentic materials are made from the authentic texts that has been defined as real-life conversation, it is not written for pedagogic purposes and it is written by native speaker that contains real language.

The selection of teaching materials is very important aspect to learn foreign language. Sources of teaching materials are widely provided in this modern era and one of the most accessible sources are internet. Authentic Materials are needed in English language teaching, especially in Vocational High School. It is one of teaching materials that helpful for the students of Vocational High School to know the real use of English in the real communication context. Using authentic materials is expected to meet an ideal teaching materials to build students' interest in learning English since there is no course book that can be ideal for any particular class (Brian, 2001) and teaching materials for vocational high school tend to be viewed as distinct and separate from general course book (Alan, 1995). However, authentic materials should be selected carefully to get the proper authentic materials that could make students interested, motivated and possibly bring authentic learning. There are two categories of authentic materials; those are authentic print materials such as bills, order forms, signs, pictures, etc. and authentic auditory materials such as video, songs, etc.

Rashid and Majid quoted from Genhard, stated that authentic materials are classified into three categories; authentic learning materials, such as radio news, cartoons, songs, etc., authentic visual materials, such as street signs, magazines, and newspapers, pictures, post cards, etc., and authentic printed materials, such as sports reports, newspapers, restaurant menus, train tickets, etc. In selecting authentic materials, there are four criteria that should be considered by the teacher such as, first, authentic materials should appropriate to basic competence and students' need, second, authentic materials should be interesting, third, authentic materials should be understandable, and fourth authentic materials should up-to-date. As quoted by Benmakholuf, Wallace suggested the following criteria when selecting authentic materials for English for Specific Purposes (ESP), there are: (1) Adequacy, the selected materials should contain appropriate language 
and information about the course. (2) Motivation, the selected materials should present interesting content in order to help students to be active and work hard in order to understand better. This criterion should be respected in order to make students understanding more effective. (3) Sequence, the selected materials should relate to the course. There should have relationship between text, activities, and the topics. (4) Diversity, the selected materials should lead to a range of classroom activities. (5) Acceptability, the selected materials should contain acceptable culture, custom and language. Those criterions that explained above, the criteria that accustomed by Wallace theory are used by the researcher to analyze and to compare findings of the study.

Authentic materials for English for Specific Purposes are needed by the students to stimulate them with their real life. So, English that is being taught in Vocational High School requires English to be more specific as the communication tools to overcome students' difficulties in the real-life communication.

Addressing the problem of students' difficulties to have a good communication skill in a specific way will considering alternatives to use the authentic materials in teaching English for Specific Purposes (ESP). The majority of students in new beginners or they are categorized in the period of transitions from secondary school to Vocational high school will have difficulties in mastering the real communication target. Introducing the special terms of target communication such hotel accommodation field, will help teacher in the process of teaching when its process refers to the use of authentic materials. It is believed will encourage students to have communication a real life condition based on their specific program. Therefore, students who learn through authentic materials in their classroom will have consistently accessible producing words. It is vital for students to get practice in dealing with written text and speech where they miss quite a few words but are still able to extract the general meaning(Harmer, 2007:273). On the other hand, the nature of these addressing problem requires the use of authentic teaching material. It is the "real life' material which prepares students for performing their professional tasks. The identification of causes also happened in SMK Negeri 2 Cirebon as the researcher had observed. The observation showed that students' speaking comprehension is lack when they got the real communication task. So it happened to encourage the teacher to not only use the material from the course book, but it should dominate to use the authentic materials in teaching English for Specific Purposes (ESP). Students are able to explore more and get the comprehensible output in the end of the learning process.

There are many previous studies from foreign researcher. Their studies are about EFL Teachers or Learners relates with the using of authentic materials. Belaid (2015) reports that some EFL teachers emphasize on regular use of the materials in their language classes, which would positively reflected on the learners' language proficiencies. Second, Khalid (2016) entitled "Authentic materials Selection in Hospitality Program at State Vocational High School (SMKN) 1 Buduran Sidoarjo". The result of this research revealed the use of authentic material selections and the criteria to select authentic materials to teach in Hospitality. However, the authentic material between teacher and students has different reasons. Third, is the research entitled "The study on the impact of authentic materials on EFL's students' achievement, retention and opinions regarding two grammar units of High School Level" by Demircan (2004). The result indicates that most of students were more successful in developing and retaining grammar knowledge while using authentic material in the classroom. Fourth, Imane (2013) reports that most of students were more successful in developing and acquiring specific knowledge in terms of Computer Science while using authentic material in the classroom and it refers to the development of ESP materials in 
teaching. Although the authentic material can be viewed from different aspects, but it is focused on enhancing students' speaking skill. This research investigated the process of teaching English for Specific Purposes (ESP) using authentic teaching materials and their responses to the process of teaching and learning English for Specific Purposes (ESP) using authentic material in the Hotel Accommodation program.

\section{METHOD}

This study used qualitative or intentionally descriptive qualitative. Descriptive qualitative is targeted to understanding a phenomenon, a process, or a particular point of view from the perspective of those involved (Ary, et all, 2010:455). Descriptive qualitative can equaled with case study. Regarding to Ary, et all., (2010:454). Case study can answer descriptive qualitative (what happened) or attempt to explain why something happen by looking at a process. According to Alwasilah (2015:68), a qualitative case study refers to phenomenon which is believed will give the source of insight and ideas. Case or phenomenon which already exists in particular places is investigated more deeply which can give a contribution of the case itself.

This study took a place in one of State Vocational High School in Kota Cirebon, namely SMK Negeri 2 Cirebon. This school is located in Dr. Cipto Mangunkusumo Street, Kota Cirebon. The aspect of why this research will be conducted in this school is, caused the school has many study programs which English is definitely taught in a specific manner or English for Specific Purposes (ESP). However, this study will only be focused on one of the programs that will investigate on how does teaching English for Specific Purposes (ESP) in Hotel Accommodation program. With the main objective is to explore students and teachers responses to the use of authentic materials in teaching English for Specific Purposes (ESP) process in introducing specific terms of Hotel Accommodation's accessibilities.

The other instruments that used to collecting data that the researcher has conducted are the transcription of observation checklist, field note, interview transcribed, audio recording, video recording, and lesson plan. Observation checklist was a tool to observe based on the experts' theory and some recommend adaptations that used during teaching English for Specific Purposes (ESP) especially in speaking class. The audio recording takes the interview; then it is transcribed into the document. The video recorded to take the audio-visual regarding to the teaching and learning English for Specific Purposes (ESP) during the investigation, then it transcribed into document. Field note used as supporting evidence of activity during the observation. Transcript is used as a support the audio and video recording in written observation and interviews' transcription. The techniques of data collection are: (1) In Depth Observation. Some of qualitative research use in depth observation to investigate and to answer the research question is each study. Frankle and Wallen (2009: 440) have argued that certain kinds of research question can be best answered by observing how people act or how things look. Caused by using participant observation, this research, therefore, will conduct the data by participating in the classroom in order to investigate the English for Specific Purposes (ESP) teaching and learning process using authentic materials. The researcher did the investigation by observing teaching and learning process through video recorded, the observation checklist and field note that had well-recorded and to be transcribed. (2) In Depth Interview. The researcher used in depth interview's guide to probe the information. The interview that the researcher used has a few of types to be asked. Types of interview that the researcher used are classroom management based on scientific approach, use of authentic teaching materials, 
teaching techniques, use of teaching aids, and the impact using authentic materials to the students' improvements. The researcher have interviewed an English teacher in handling English for Specific Purposes (ESP) course especially in hotel accommodation program, namely Mrs. Sutini, and some selected students of State Vocational High School 2 Cirebon especially in the tenth grade of hotel accommodation program that supported the data. In both teacher and students are required to response the use of the authentic materials in teaching and learning English for Specific Purposes (ESP). The interviews will have audio recorded to be transcript into document. In this study, the researcher use both of English and Bahasa Indonesia becoming language in the interview questions to get the detail in the data, then the researcher had translated Bahasa Indonesia transcription into English in the research finding and discussion. (3) Document Study. In the document analysis, the researcher used lesson plan study document and interviews' transcription regarding to the planning and evaluating of teaching English for Specific Purposes (ESP) in the tenth grade of hotel accommodation program, those were given in different phase of time. Lesson plan taken from the English teacher before the researcher conducting the observation, while the interview taken from teacher and students' responses after the researcher conducting the observation.

\section{FINDINGS}

\section{ESP Teaching Process}

The process of teaching and learning English for Specific Purposes (ESP) in the tenth grade students of hotel accommodation program is following the real communication English as language for professional purposes. They are focusing on enhancing students' speaking skills and communicative target language competence basically in their own specific program. Based on Carter and Nunan (2001), communicative language teaching there appeared a change in focus from English as a system to be studied to English as a means of communication in syllabus design. That statement in line with the course syllabus that applied in the teaching process which is used authentic materials to teach the students in the tenth grade of hotel accommodation program were examined have been different largely within the general language teaching framework. The content selection was done based on learners' communicative needs. It is used the materials that taken from their surrounding and specifically authentic in terms of hotel accommodation program.

Students of hotel accommodation program are trained to be focus on the hotel accommodation accessibilities as their specific course in English for Specific Purposes (ESP). As the statement above, English for Specific Purposes (ESP) teaching are examining by the materials that will be used as the teaching materials. The materials should be focus on the specific program to engage the purpose of teaching itself. The basic elements that have to be taken into consideration in this teaching and learning process are learner needs, goals, and motivation. During teaching and learning speaking process here, the teacher gave the instructions to the students in a real communication tasks clearly, fluently, accurately and use English to enhance the students' proficiency. But sometimes the teacher used Bahasa Indonesia to confirm the students who do not understand yet about the explanation.

English for Specific Purposes (ESP) teaching and learning process considered the authentic material as English for Specific Purposes (ESP) teaching materials. Because the authentic material provides the real-life communication and it is natural language used by native or competent speaker of language. This is such illustrations of what students will encounter in real life if they come into contact with target language speaker. The students' 
needs are the prior attention to determine teaching materials. In this learning process, the authentic materials are measured by the students allowed to explore their own learning materials to the internet and they got the recommendation sources from the teacher in every single class meetings in each chapter.

Teaching and learning process in the tenth grade students of hotel accommodation at Government Vocational High School 2 Cirebon followed their planning materials based on its syllabus in a semester. The syllabus from the centered government is discussed before the process of teaching and learning begins, it based on the teacher's curriculum committees, it can be called MGMP. Content of the materials adjust the students' needs in terms of hotel accommodation accessibilities according to students' need analysis and identification. The standard competencies that the teacher used in Vocational High School are generally relevance with Senior High School. They are positioned for the same level of competencies. It can be stated that the topic of materials is similar but a quite different with the most specification course in Vocational High School. The topics that discussed are courses of pronoun, descriptive text, narrative text, recount text and sing a song.

In this teaching process, English for Specific Purposes (ESP) is taught by the teacher through the authentic materials based on the appropriate selections. These learning material selections are according to students' needs and identification before teaching, and students are interested while teaching. Teacher as the facilitator provides the authentic materials and comprehends the authentic materials as well. Planning the classroom activities includes preparing the recommendation sources to the students and mastering the material in every single meeting are the obligation for the teacher. Teacher did not teach based on the course book but she taught by using authentic materials and following the learning syllabus based on the curriculum. In every meeting, students in the tenth grade of hotel accommodation program let to bring smartphones in terms of exploring and looking forward only for the materials. It means that the materials are taken by their surroundings, including from the internet browsing. The teacher asks the students to freely access and browse about the learning materials from the internet based on the topic, and the teacher will explain based on the questions of the students.

\section{Teacher and Students Responses}

State Vocational High School 2 Cirebon has five specific departments that classified as the tourism department including hotel accommodation program. These teaching and learning process addressed English for Specific Purposes (ESP) in State Vocational High School 2 Cirebon is being taught by using the authentic materials. The teaching and learning English for Specific Purposes (ESP) process using the authentic materials is required to teach the students that majored in hotel accommodation program, because the students will relatively close to the use of English as communication tools in the real communication task. These teaching and learning English for Specific Purposes (ESP) using the authentic materials is taught based on the stage of scientific approach. Stages of scientific approach are namely observing, questioning, experimenting, associating and communicating.

English for Specific Purposes (ESP) materials content selection or the authentic teaching materials was done based on learners' communicative needs. It is used the materials that taken from their surrounding and specifically authentic in terms of hotel accommodation program. According to Carter and Nunan (2001), English to be studied as a system should change the formation into English as a means of communication in 
syllabus design. The students of hotel accommodation program are trained to be focus on the hotel accommodation accessibilities as their specific course in English for Specific Purposes (ESP). The teacher uses these teaching techniques to develop students' mental ability in exploring the materials by themselves encouragement and let them to look forward by using search engine.

English for Specific Purposes (ESP) is English that especially taught in a specific program. These teaching and learning processes took in hotel accommodation program effectively. It usually taught in the specific ways focus to the departments. The tenth grade students in hotel accommodation program set to be prepared in the real communication tasks. As the students, the use of the authentic materials is required to learn and introduce some target language that required in the hotel accommodation program. It occurs since the students that majored in hotel accommodation program will relatively closed to the use of English as communication tools in the real communication task.

\section{DISCUSSION}

Teaching English for Specific Purposes (ESP) in the tenth grade students of hotel accommodation program is relevance with other teaching in different vocational high schools. Topics of the materials in their level are generally the same with senior high school. But they are some differences in the process of teaching and learning English for Specific Purposes (ESP) in terms of learning materials that State Vocational High School 2 Cirebon used. They are using the authentic materials to the process of teaching and learning English for Specific Purposes (ESP). In this English for Specific Purposes (ESP) teaching and learning process, teacher facilitates students by asking and giving students about the recommendation sources based on the topic of learning material in every meeting. The teacher taught by using the authentic materials that followed the learning syllabus based on the curriculum.

The tenth grade students of hotel accommodation program are asked to find out the appropriate materials but the teacher did not forget to offer the recommendation sources for those appropriate materials sources. The teacher explains and offers practice to the students of the tenth grade of hotel accommodation in specific academic vocabulary and expressions in English for Specific Purposes (ESP) learning. That statement means that the teacher has to comprehend the whole materials and guide students based on their questions. The students mentioned that by these authentic materials, students enjoyed the teaching and learning process of English for Specific Purposes (ESP) and they are asked to be responsible in gaining more sources by students' own self access in the daily real-life communication explored by their surrounding evidently.

In teaching English for Specific Purposes (ESP) process considered the authentic material as the most appropriate learning materials. Because English for Specific Purposes (ESP) teaching materials should provide the real-life communication so it represented natural language used by native or competent speaker of language. The students' needs are the priorities to determine teaching materials. Teaching and learning English for Specific Purposes (ESP) that using authentic materials is objectively achieved the real communication tasks. In this learning process, the authentic materials are measured by the students allowed to explore their own learning materials to the internet and they got the recommendation sources from the teacher in every single class meetings in each chapter.

English for Specific Purposes (ESP) teaching and learning process in the tenth grade students of hotel accommodation at State Vocational High School 2 Cirebon 
followed the syllabus from the centered government that was discussed before the process of teaching and learning is began, it based on the teacher's curriculum committees, it can be called MGMP. In terms of hotel accommodation program, the content of the learning materials adjust the students' needs and interests according to students' needs analysis and identification. The standard and basic competencies that the teacher used in State Vocational High School 2 Cirebon are generally relevance with other Senior High School in the same level. It occurs since they are positioned in the same level of target competencies. The topic of the learning materials is similar but different with the learning materials that used in Vocational High School for those most specification courses. The topics that discussed are pronoun, descriptive text, narrative text, recount text and sing a song. Those topics are discussed in the whole process of teaching and learning English for Specific Purposes (ESP) using the authentic materials.

The authentic learning material facilitates and helps the teacher with feedback on the efficiency of the course in teaching English for Specific Purposes (ESP) course. It is effective to engage the real life communication. The students are free to explore the materials by themselves, but the teacher does not forget to give the source about the materials based on the links or the websites. The teacher also did not forget to focus on the learning objectives. These kinds of topic are objectively used the imaginative real life tasks, for example pronoun, it introduced students to the real communication tasks for a serving task. While conducting the English for Specific Purposes (ESP) teaching and learning process, students are invited to practice the conversation in a real communication. They are asked to group themselves practice about several tasks in terms of hotel accommodation accessibilities, they are laundry, room services, pool attendant, food and beverage, concierge, housekeeping and practice to greet up guests includes check in and check out called as front office (FO). Students in each group are assigned to speak about the services in a hotel accommodation accessibilities using pronoun in the effective ways. Teaching and learning process in the tenth grade students of hotel accommodation at Government Vocational High School 2 Cirebon conducted in the real communication tasks.

The assessments focused on the target of specification based on the program. They encourage enhancing students speaking skills as the main outcome of the process teaching and learning English for Specific Purposes (ESP). The other learning materials are types of texts, such as descriptive text, narrative text, and recount text. These topics are relatively closed to the real communication tasks. The process of teaching and learning English for Specific Purposes (ESP) are also related to each daily real-life condition. For the first types of text is descriptive text, students are asked to look forward to the internet for the example, generic structures, language features related to the topic discussion by their own mobile phones.

The process of teaching and learning English for Specific Purposes (ESP) in the tenth grade students of hotel accommodation program is following the real communication tasks in a specific target language. It means that English as language for professional purposes in terms of hotel accommodation accessibilities. They are focusing on enhancing students' speaking skills and communicative target language competence basically in their own specific program. Standard and basic competencies used by the teacher used in State Vocational High School 2 Cirebon are generally relevance with other Vocational and Senior High School. Although the students of the tenth grade in hotel accommodation program are positioned for the same level of competencies from the other departments, the teaching and learning English for Specific Purposes (ESP) teaching materials took the 
authentic materials as the focus to enhance students' competencies in speaking. It can be stated that the authentic materials set in the process of teaching and learning English for Specific Purposes (ESP) and determined some target language that should be master by the students.

Scientific approach in the English for Specific Purposes (ESP) learning process is applied within the difficulties. Although its content of material selection was done based on learners' communicative needs, and it is used the materials that taken from their surrounding, specifically, authentic in terms of hotel accommodation program. But, the teacher felt difficulties to apply the stage of scientific approach itself because the students might not ready to study. The students of the ten grade in hotel accommodation program are positioned in the low of thinking because the students mindset still expected that the teacher will explain from the beginning until the end and take a note. Otherwise, the English for Specific Purposes (ESP) teaching and learning process required students to be active to do search engine by themselves. Communicative language teaching there appeared a change in focus from English as a system to be studied to English as a means of communication in syllabus design (Carter and Nunan, 2001). The students of hotel accommodation program are trained to be focus on the hotel accommodation accessibilities as their specific course in English for Specific Purposes (ESP).

English for Specific Purposes (ESP) teacher in the classroom is a knowledge provider and a facilitator of students' learning and no more as a resourceful authority. These statements in line with the process of teaching and learning English for Specific Purposes (ESP) in the tenth grade students of hotel accommodation program that teacher guided as the facilitator. When the teacher guides as the facilitator of the students then the students are as the centered. The whole process of teaching and learning used studentcentered learning that only focus on the students' competencies progress. The use of authentic material is interpreted to make learner sound more natural when participating in conversation and discussion. The teacher brings the authentic materials into the classroom activity while it means teacher asked to the students to open and browse to the internet by themselves. Students are asked for look forward the appropriate materials, but the teacher does not forget to give the recommendation for those appropriate materials sources.

\section{CONCLUSION}

This study was expected to gain the answer of two research questions about the teaching and learning English for Specific Purposes (ESP) process using the authentic materials and the responses of the teacher and students to use of authentic material in the process of the teaching and learning English for Specific Purposes (ESP). Based on the results of this study, the researcher concludes the answer of the research questions as the following:

1. The teaching and learning English for Specific Purposes (ESP) process in the tenth grade students of hotel accommodation program that using the authentic materials in formal learning situation at State Vocational High School 2 Cirebon already did in good work. The indicators are from the teacher who have good performance in conducting teaching and learning process of English for Specific Purposes (ESP) because the teacher have fulfilled the criterion of classroom observation and authentic materials selection in teaching. Related to the aims of learning, communicative approach and students' centered-learning as the method in conducting the class of the students who categorized in the tenth grade of hotel accommodation program. Next indicator from the 
students who have good learning desire to follow and perform English for Specific Purposes (ESP) class in the real communication tasks. They have good enthusiasm in learning English. The last indicator is learning material, they use the authentic materials as the real life material that close to the real condition. However, with the authentic materials that students used by optimizing the search engine, so far did not have problems related to the learning materials. The teaching and learning English for Specific Purposes (ESP) conducted well.

2. The teacher have a positive response to the teaching and learning English for Specific Purposes (ESP) process using the authentic materials because these teaching and learning materials assumed that has a good contribution to promote the real communication tasks in terms of hotel accommodation program. The authentic materials help the teacher to fulfill the target language that should be master by the students in the hotel accommodation program. Besides its materials are purposed to engage the students with the real communication task, it also provide the language items that have to be comprehended by the students. Moreover the students also have a positive response to the learning English for Specific Purposes (ESP) process using the authentic materials. They relatively had a good comprehension in speaking English in terms of English for Specific Purposes (ESP) after they are taught by the teacher using the authentic materials because these teaching and learning materials took from the students' environment by their surroundings. The authentic materials in English for Specific Purposes (ESP) learning process required in optimizing the use of search engine to search about the materials. The teacher aims to equip the students with the ability in the real communication tasks in terms of hotel accommodation program.

\section{REFERENCES}

Azza, Benmakholuf Nour El Imane. (2013). ESP Material Selection: The case of Second Year Computer Science Students of Ouargla University. Dissertation. Algeria: Kasdi Merbah Ouargla University.

Basturkmen, H. (2006). Ideas and Options in English for Specific Purposes. London and New Jersey: ESL and Applied Linguistic Professional Series: Eli Hinkel, Edition

Belaid. (2005).Using Authentic Material in the Foreign Language Classroom: Teacher attitudes and Perceptions in Libyan Universities. Undergraduate Thesis. Malang: Universitas Negeri Malang.

Brown, Douglas. H. (2007) Principles of Language Learning and Teaching (Fifth Edition). White Plains, NY: Pearson Education.

Brown, Douglas. H. (2003). Language Assessment (Principles and Classroom Practices). California: Longman.

Creswell, John W. Qualitative Inquiry\& Research Design: Choosing Among Five Approarches. Second Edition. California: Sage Publication Inc.

Demircan. (2004). The study on the impact of authentic materials on EFL's students' achievement, retention and opinions regarding two grammar units of High School Level. Undergradute Thesis. Malang: Universitas Negeri Malang.

Dudley, E. and St John. (1998). Developments in ESP a Multi-Disciplinary Approach. Cambridge:Cambridge University Press. 
Ellis, R. (2012). Language Teaching Research and Language Pedagogy. Oxford: WileyBlack Well.

Fachrurrazy. (2014). Teaching English as a Foreign Language for Teachers in Indonesia. Malang. State University of Malang Press.

Harmer, J. (2002). The Practice of English Language Teaching (3rd Edition). New York: Longman.

Hutchinson, T. \& Waters, A. (1987). English for Specific Purposes: a learner-centred approach. England: Cambridge University Press.

Johns, A.M. and Dudley, E. (1991). English for Specific Purposes: International in Scope Specific Purpose.TESOL Quarterly Vol. 25. N 2: pp 297-314

Kholik, Abdul. (2016). Authentic Materials Selection in Hospitality Program at State Vocational High School (SMKN) 1 Buduran Sidoarjo. Undergraduate Thesis. Surabaya: IAIN Sunan Ampel.

Kilickaya, Ferit. Authentic Materials and Cultural Content in EFL Classroom. The Internet TESL Journal 10 (7), 2004, from http://itelslj.org/Techniques/KilickayaAuthenticMaterial.html, accessed on 11st March 2018 at $8.59 \mathrm{pm}$.

Lamri, C.E., DR. (2016). An Introduction to English for Specific Purposes (ESP). Tlemcen: Abou Bekr Belkaid University.

Lodico, Marguirete G., Spaulding, Dean T., \& Voegtle, Katherine H. (2006). Method in Educational Research: From Theory to Practice. San Fransisco: Jossey- Bass.

Long, M.H \& Crookes, G. (1993). Units if Analysis in Syllabus Design: The Case for the Task. In Crookes and S.M Grass (Ed). Tasks in a Pedagogical Context.Cleveland, UK: Multilingual Matters 9-44.

Mackay, R. And Mountford, A. (1978). English for Specific Purposes: A case study approach. London: Longman.

Martinez, Alejandro G. Authentic Materials: An Overview. Karen's Linguistics Issues, 2002, from http://www.metu.edu.tr.html, accessed on March 13th, 2018 at 14.55 pm.

Mc. Donough, S. (1984). ESP in Perspectives. London and Glagow: Collins ELT.

Mumby, J. (1978). Communicative Syllabus Design. Cambridge: Cambridge University Press.

Nunan, David \& Ronald Carter. (2001). The Cambridge Guide to Teaching English to Speaker of Other Languages. Cambridge: Cambridge University Press.

Strevens, P. (1977). New Orientations in the Teaching of English. Oxford University Press.

Troike, and Saville, M. (2006). Introducing Second Language Acquisition. Cambridge: Cambridge University Press. 